\title{
CAPILLARY RESISTANCE AND SKIN-FOLD THICKNESS IN PATIENTS WITH RHEUMATOID ARTHRITIS EFFECT OF CORTICOSTEROID THERAPY
}

\author{
B. M. GREENWOOD
}

Postgraduate Medical School, London

The skin of the dorsum of the hand may become transparent, enabling the underlying structures to be seen with increased clarity. This appearance is seen occasionally in elderly normal subjects but occurs more frequently in patients with rheumatoid arthritis. Transparent skin is associated with osteoporosis in patients with rheumatoid arthritis and other non-rheumatic disorders, and it has been suggested that a defect of connective tissue collagen underlies this relationship (McConkey, Fraser, Bligh, and Whiteley, 1963; McConkey, Fraser, and Bligh, 1965).

Capillary resistance is often reduced in patients with rheumatoid arthritis (Potter and Wigzell, 1957). The way in which petechiae are produced by the application of negative pressure to the skin is not fully understood, but they can develop with or without rupture of the capillary wall (Hare and Miller, 1951; Kramár, 1962). Capillaries are surrounded by a fine sheath of connective tissue (Zweifach, 1955), damage to which facilitates capillary rupture and the diapedesis of red cells through the capillary wall. This may account for the diminished capillary resistance seen in patients with connective tissue disorders.

The characteristics of the skin of the hand and capillary resistance may both be influenced by the integrity of the dermal connective tissue. A study has therefore been made of the relationship between these two factors in normal subjects and in patients with rheumatoid arthritis, some of whom were receiving corticosteroid therapy.

\section{Materials and Methods}

96 patients with established rheumatoid arthritis and 115 hospital visitors were studied. The visitors were all in good health and only a small proportion were relatives of patients with arthritis. All the patients with rheumatoid arthritis admitted to Hammersmith Hospital, or seen personally in the out-patient department, during a 4month period were investigated. No deliberate selection of cases was made, but most of the patients studied had a moderate or severe form of the disease, and one third of on them were receiving steroid therapy.

The backs of the hands were carefully examined for the presence of transparent skin and purpura. In doubtful cases the skin was designated normal. The thickness of a double skin-fold was measured over the mid part of the fourth metacarpal using a pair of constant pressure calipers. Three readings were taken from each hand and the mean recorded.

Capillary resistance was determined by a negative pressure method using a suction cup of $2.5 \mathrm{~cm}$. diameter. Pressures were recorded on an anaeroid manometer connected to the suction chamber. A system of clamps allowed the gradual application and release of negative pressure. Varying pressures were applied to adjacent areas of the skin of the flexor surfaces of the forearms. Provided that measurements were restricted to the midline, consistent results could be obtained from adjoining skin areas. The minimal pressure which, when applied for 1 minute, produced one or more petechiae away from the rim of the suction cup was taken to indicate the capillary resistance. As many as possible of the variable factors known to influence capillary resistance were $\bar{\partial}$ standardized (Hare and Miller, 1951). Recordings were $\dot{0}$ made during a limited period of the year but it was not possible to carry out all estimations at the same time of $\delta$ day. No measurements were taken during the premenstrual or menstrual periods as capillary resistance is $\mathrm{O}$ known to fall at this time (Clemetson, Blair, and Brown, 1962). At the time of this study none of the patients $\frac{7}{0}$ investigated was receiving treatment with gold which may also lower capillary resistance (Heikinheimo, 1953). The N skin was examined for petechiae under constant illumination. By surface heating a constant skin temperature $\tilde{O}$ was achieved, as Potter and Duthie (1961) have shown the effect of temperature in altering capillary resistance in patients with rheumatoid arthritis.

The duration and activity of the disease were noted in every patient with arthritis. The degree of involvement $\stackrel{D}{\leftrightarrow}$ of all major joints was graded from 1 to 3 and a numerical total obtained, giving an indication of the overall severity $\frac{{ }^{\circ}}{+}$ of the disease. In all patients the erythrocyte sedimenta- $\frac{}{\mathbb{D}}$ tion rate (E.S.R.) (Westergren) was measured and the 
Waaler-Rose test for rheumatoid factor was performed. Differences between means and correlation coefficients have been considered significant when they exceeded twice their standard error. Because of a slight difference in age distribution between patients and control subjects, a correction has been undertaken for measurements for which analysis showed a significant linear relation with age. Values were adjusted for each subject to those that would have been expected had the individual been 50 years old. This was achieved by extending a line parallel to the line of the regression equation from the observed point to that of the 50-year mark. These corrections have enabled more accurate comparisons to be made between the various groups studied.

\section{(1) Capillary Resistance}

The mean values and standard deviations obtained for capillary resistance among patients and control subjects are shown in Table I. A significant negative correlation was found between capillary resistance and age among control subjects, among male patients receiving treatment with steroids, and among untreated female patients. Table II shows the results obtained for capillary resistance after correction of the observed values to those that would have been expected had each individual been 50 years old. Capillary resistance was significantly lower among both male and female untreated patients than among the control subjects. The capillary resistance of patients receiving treatment with steroids was higher than that of the control subjects but the difference was not significant. After correction for age variation, capillary resistance was found to be higher in both male patients and control subjects than in their female counterparts. No correlation was found between the level of capillary resistance and the duration, activity, or severity of arthritis. A high E.S.R. was associated with a significantly lower capillary resistance among female but not among male patients. Among both treated and untreated patients, capillary resistance was lower in those with a positive Waaler-Rose test at a titre of $1: 16$ or greater than in those who were sero-negative but the differences were not statistically significant.

Four untreated patients with rheumatoid arthritis were given prednisone $30 \mathrm{mg}$. daily for 3 days. A mean rise in capillary resistance of $100 \mathrm{~mm}$. $\mathrm{Hg}$ was produced in three of them; the fourth patient, who showed no response, was an old lady with quiescent arthritis whose capillary resistance was already greater than that to be expected in a normal person of her age.

\section{(2) Skin Thickness}

Mean values and standard deviations for skin thickness measurements are shown in Table III (overleaf).

A significant inverse relationship was found between skin-fold thickness and age among the control subjects of both sexes, the male patients receiving treatment with steroids, and the untreated female

TABLE I

MEAN VALUES OF CAPILLARY RESISTANCE WITH STANDARD DEVIATIONS (IN PARENTHESES) OF PATIENTS AND CONTROL SUBJECTS, BY SEX

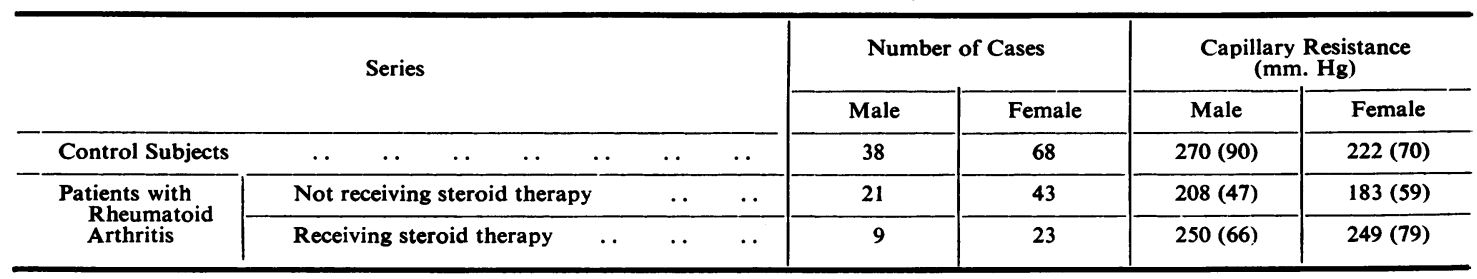

TABLE II

MEAN VALUES OF CAPILLARY RESISTANCE WITH STANDARD DEVIATIONS (IN PARENTHESES) OF PATIENTS AND CONTROL SUBJECTS AFTER CORRECTION FOR AGE VARIATION, BY SEX

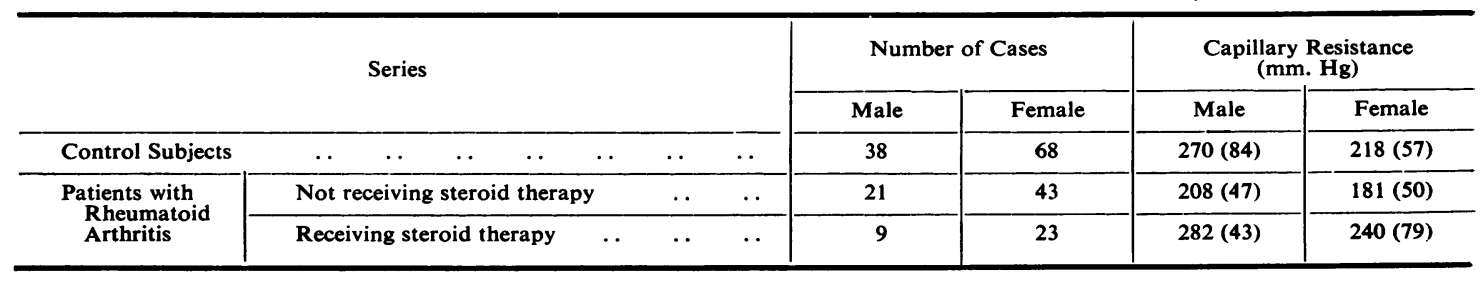


patients-the same groups in which a relationship was found between capillary resistance and age. Table IV shows the results obtained for skin-fold thickness measurements after correction of the observed values to those that would have been expected had each individual been fifty years old. After correction for age variation it was found that there was no significant difference in skin-fold thickness between the untreated patients and the control subjects. The skin of the patients receiving steroids was, however, significantly thinner than that of the control subjects. The skin of the steroid-treated patients was thinner than that of the untreated patients but the difference was only significant among the females. After correction for age variation, the skin was thinner in the female patients and control subjects than in their male counterparts. No correlation was found between skin-fold thickness and the duration, activity, or severity of the disease. Among both steroid-treated and untreated patients the skin was thinner in those who were sero-positive than in those who were sero-negative, but the difference was significant only among the small group of male patients receiving steroid therapy. No relationship was found between skin-fold thickness measurements and the total dosage of steroids that had been given.

\section{(3) Relationship between Capillary Resistance and} Skin-fold Thickness

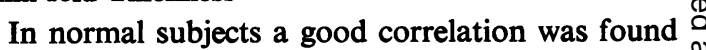
between capillary resistance and skin-fold thickness is although there was a wide scatter of points around $\overrightarrow{0}$ the regression line (Fig. 1, opposite). Among the untreated patients with arthritis the relationship was $\vec{\sigma}$ still present but less marked (Fig. 2, opposite). The relationship was lost among the patients who were $\overline{0}$ receiving treatment with steroids (Fig. 3, opposite). on

\section{(4) Transparent Skin}

The incidence of transparent skin at different ages 0 among patients and control subjects is shown in Table V. Transparent skin was found more fre- $\bar{z}$

TABLE III

MEAN VALUES OF SKIN-FOLD THICKNESS WITH STANDARD DEVIATIONS (IN PARENTHESES) OF PATIENTS AND CONTROL SUBJECTS, BY SEX

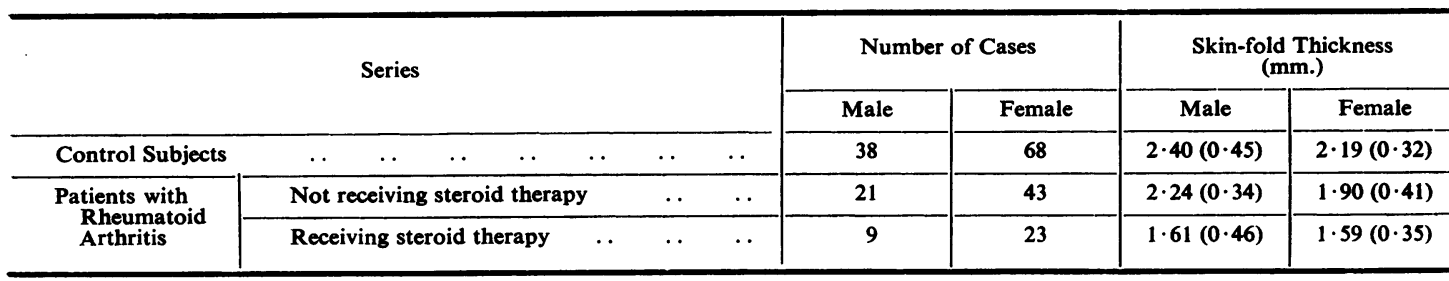

TABLE IV

MEAN VALUES OF SKIN-FOLD THICKNESS WITH STANDARD DEVIATIONS (IN PARENTHESES) OF PATIENTS AND CONTROL SUBJECTS AFTER CORRECTION FOR AGE VARIATION, BY SEX

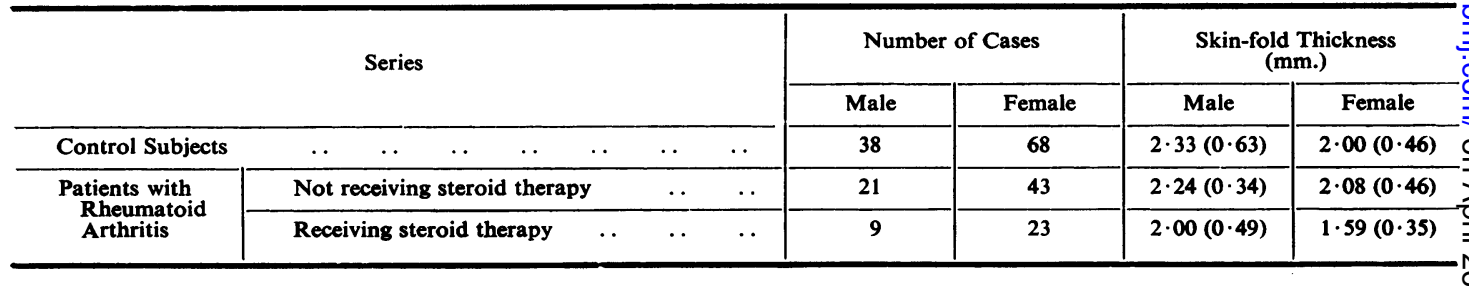

TABLE $\mathbf{V}$

INCIDENCE OF TRANSPARENT SKIN AT DIFFERENT AGES IN PATIENTS AND CONTROL SUBJECTS

\begin{tabular}{|c|c|c|c|c|c|c|c|c|c|c|}
\hline \multirow{2}{*}{\multicolumn{2}{|c|}{ Series }} & \multicolumn{7}{|c|}{$\begin{array}{c}\text { Age Group } \\
\text { (yrs) }\end{array}$} & \multirow{2}{*}{$\begin{array}{c}\text { Total Number } \\
\text { with } \\
\text { Transparent } \\
\text { Skin }\end{array}$} & \multirow{2}{*}{$\begin{array}{c}\text { Total } \\
\text { Number } \\
\text { of } \\
\text { Cases }\end{array}$} \\
\hline & & $<20$ & $21-30$ & $31-40$ & $41-50$ & $51-60$ & $61-70$ & $>70$ & & \\
\hline Control Subjects & . & $0 / 9$ & $0 / 19$ & $0 / 15$ & $0 / 20$ & $0 / 19$ & $0 / 15$ & $3 / 9$ & 3 & 106 \\
\hline \multirow{2}{*}{$\begin{array}{l}\text { Patients with } \\
\text { Rheumatoid } \\
\text { Arthritis }\end{array}$} & Not receiving steroid therapy & $0 / 1$ & $0 / 3$ & $0 / 3$ & $2 / 14$ & $4 / 21$ & $5 / 15$ & $5 / 7$ & 16 & 64 \\
\hline & Receiving steroid therapy $\ldots$ & & $0 / 1$ & $3 / 4$ & $5 / 8$ & $8 / 11$ & $5 / 6$ & $2 / 2$ & 23 & 32 \\
\hline
\end{tabular}




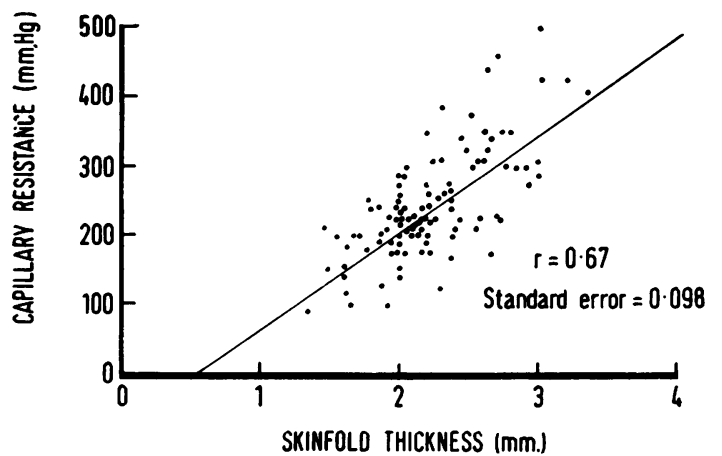

Fig. 1.-Capillary resistance and skin-fold thickness in 106 control subjects.

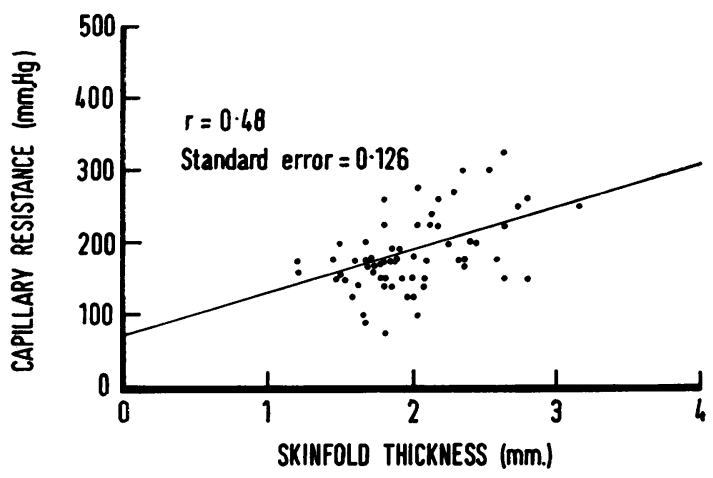

Fig. 2.-Capillary resistance and skin-fold thickness in 64 patients with rheumatoid arthritis not receiving steroid therapy

quently among the untreated patients than among the control subjects $(P<\cdot 001)$, and in the arthritic patients it tended to occur at an earlier age. Among the untreated patients it was seen more commonly in females than in males-fourteen of 43 female patients were postmenopausal. Transparent skin occurred much more frequently among the patients on steroid treatment than among the untreated patients $(P<\cdot 001)$, and in the steroid-treated patients it was equally common in males and females. It was noted more often in those patients with a long history of arthritis and those with more severe disease. Transparent skin was on the whole thin skin, although there was some overlap between the

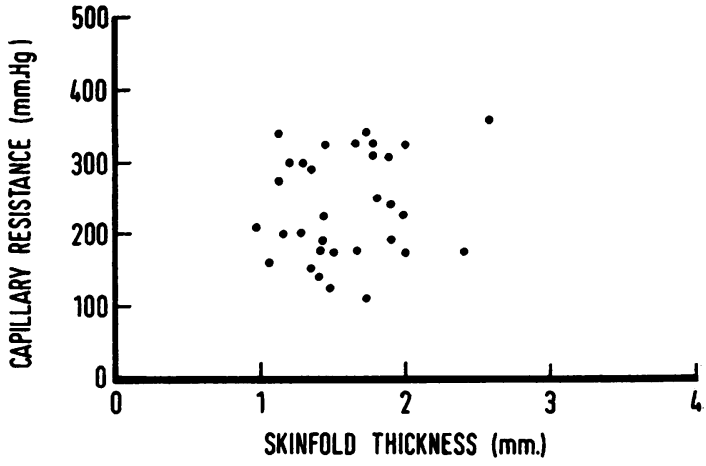

Fig. 3.-Capillary resistance and skin-fold thickness in 32 patients with rheumatoid arthritis receiving steroid therapy.

measurements of skin-fold thickness obtained in i those with transparent skin and those with normal is skin (Table VI).

TABLE VI

RELATIONSHIP OF SKIN-FOLD THICKNESS AND TRANSPARENT SKIN IN PATIENTS WITH RHEUMATOID ARTHRITIS, BY SEX

\begin{tabular}{|c|c|c|c|c|c|}
\hline \multirow{2}{*}{\multicolumn{3}{|c|}{ Skin }} & \multirow{3}{*}{\begin{tabular}{l}
\multicolumn{1}{c}{ Sex } \\
Male \\
Female
\end{tabular}} & \multicolumn{2}{|c|}{ Skin-fold Thickness (mm.) } \\
\hline & & & & \multirow{2}{*}{$\begin{array}{c}\text { Mean } \\
2 \cdot 28 \\
2 \cdot 02\end{array}$} & \multirow{2}{*}{$\begin{array}{c}\text { Range } \\
1 \cdot 67 \rightarrow 2 \cdot 78 \\
1 \cdot 50 \rightarrow 3 \cdot 15\end{array}$} \\
\hline Normal .. & $\cdots$ & $\cdots$ & & & \\
\hline Transparent & $\cdots$ & $\cdots$ & $\begin{array}{l}\text { Male } \\
\text { Female }\end{array}$ & $\begin{array}{l}1 \cdot 56 \\
1 \cdot 53\end{array}$ & $\begin{array}{l}0.98 \rightarrow 2.03 \\
1.06 \rightarrow 2.00\end{array}$ \\
\hline
\end{tabular}

(5) Purpura

Purpura of the senile or steroid type were seen in four of 64 untreated patients and in one of 106 control subjects (Table VII). This difference is only just significant $(P=\cdot 05)$. Purpura were found much more frequently in the patients receiving steroid therapy than in the untreated patients or the control subjects $(P<\cdot 001)$. Capillary resistance in the patients with steroid purpura was normal: there was no difference in capillary resistance between steroid-treated patients with purpura and those without. The occurrence of purpura was closely related to the presence of transparent skin for they were found in over half the patients with transparent skin and were not observed in any subject with a normal skin.

TABLE VII

INCIDENCE OF PURPURA AT DIFFERENT AGES IN PATIENTS AND CONTROL SUBJECTS

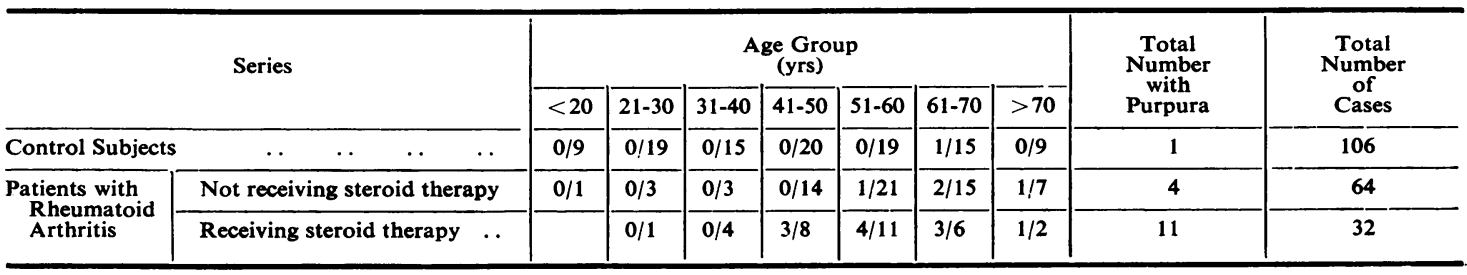




\section{Discussion}

Potter and Wigzell (1957), using a negative pressure method, found a reduction in capillary resistance in a group of patients with rheumatoid arthritis who were apparently not receiving steroid therapy. As in the present study they found no relation between the diminution of capillary resistance and the duration, activity, or severity of the disease. Using a cuff method, Warter, Drezner, and Horoschak (1946) also found diminished capillary resistance in a small number of patients with rheumatoid arthritis. The effect of steroid therapy in increasing capillary resistance in patients with rheumatoid arthritis has been shown by Robson and Duthie (1950). Both ACTH and intramuscular cortisone were found to produce a significant rise in capillary resistance when given to a small series of patients with the disease. In the present survey a similar response was observed in three of four patients when prednisone was administered. Capillary resistance has been increased in experimental animals by the administration of steroids and has been observed as a result of the increased output of autogenous steroids occurring under stress (Kramár, 1953). Heikinheimo (1953), however, found capillary resistance elevated in some patients with rheumatoid arthritis and noted that it fell when ACTH and steroids were administered. These contradictory results may be partially explained by the fact that in Heikinheimo's study the supraclavicular fossa was used as the test site and that the steroid given was desoxycortisone which has little anti-inflammatory action.

Administration of steroids was found to be associated with a reduction in skin-fold thickness in patients with rheumatoid arthritis. The difference in skin-fold thickness between treated and untreated patients could not be explained by any differences in the clinical features of the two groups for it was present after correction for age variation and neither the duration, severity, or activity of the disease was found to be related to the thickness of the skin.

A common dependence on the integrity of the dermal connective tissue may account for the relationship observed between capillary resistance and skin-fold thickness among the control subjects and the untreated patients. The absence of this relationship among the patients receiving steroid therapy is explained by the action of steroids in reducing skin thickness whilst at the same time restoring capillary resistance to a normal level.

Transparent skin was found more commonly among the untreated patients with rheumatoid arthritis than among the control subjects, but was even more frequent among the patients receiving steroid therapy. McConkey and others (1965) described the increased incidence of transparent skin in patients with rheumatoid arthritis. They also noted a greater incidence of transparent skin among steroid-treated patients than among untreated patients, but in their series the difference did not reach a significant level. Among their arthritic patients they found an association between skin transparency and osteoporosis. In the present investigation no study was made of bone density but among untreated patients the occurrence of transparent skin was almost entirely restricted to postmenopausal female patients who are much more prone to osteoporosis than premenopausal subjects.

The occurrence of purpura was found to be closely related to the presence of transparent skin. Lowering of capillary resistance was not found to be a factor in the production of steroid purpura. Whether this also applies to senile purpura, believed $N$ to have a similar pathogenesis to steroid purpura, is unknown.

Loss of collagen has been described in the atrophic

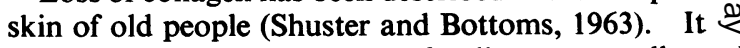
has been suggested that loss of collagen may allow $\vec{\bullet}$ the unimpeded spread of blood through a wide area of skin producing the characteristic pattern of steroid and senile purpura (Scarborough and Shuster, 1960; Shuster and Scarborough, 1961). Alteration of the structure of the dermal connective tissue may therefore be the common factor underlying the frequent occurrence of transparent skin, purpura, and reduction of skin-fold thickness observed in patients with rheumatoid arthritis receiving steroid therapy. The action of steroids in restoring the diminished capillary resistance of patients with rheumatoid arthritis must be independent of its action on the skin for damage to the dermal connective tissue might be expected to lower capillary resistance. Whether these actions of corticosteroids are restricted to patients with rheumatoid arthritis is unknown.

\section{Summary}

Capillary resistance and the characteristics of the skin of the dorsum of the hands were studied in $96 \mathrm{~N}$ patients with rheumatoid arthritis and 106 control $N_{\omega}^{N}$ subjects. It was found to be low in the rheumatoid 0 arthritics not receiving steroid therapy and normal in 6 treated patients. Skin-fold thickness was normal $\underset{\varnothing}{\overparen{D}}$ in patients not receiving steroid therapy and reduced $\stackrel{\odot}{+}$ in treated patients. A relationship was found be- $T$ tween capillary resistance and skin-fold thickness in the controls and untreated patients but not in those 
on steroids. Transparent skin and purpura occurred much more often in treated patients. It is suggested that in patients with rheumatoid arthritis steroids induce an alteration in the dermal connective tissue, accounting for the frequent occurrence of transparent skin, purpura, and loss of skin-fold thickness.

I should like to thank Dr. J. T. Scott for his encouragement and helpful advice.

\section{REFERENCES}

Clemetson, C. A. B., Blair, L., and Brown, A. B. (1962). Ann. N.Y. Acad. Sci., 93, 279.

Hare, F. W., and Miller, A. J. (1951). A.M.A. Arch. Derm. Syph., 64, 449.

Heikinheimo, R. (1953). Ann. Med. intern. Fenn., 42, Suppl. 15.

Kramár, J. (1953). Amer. J. Physiol., 175, 69.

(1962). Blood, 20, 83.

McConkey, B., Fraser, G. M., and Bligh, A. S. (1965). Ann. rheum. Dis., 24, 219. $-, \frac{}{693},-\longrightarrow$, and Whiteley, H. (1963). Lancet, 1,

Potter, J. L., and Duthie, J. J. R. (1961). Ann. rheum. Dis., $20,144$.

- and Wigzell, F. W. (1957). Ibid., 16, 357.

Robson, H. N., and Duthie, J. J. R. (1950). Brit. med.J., 2, 971 .

Scarborough, H., and Shuster, S. (1960). Lancet, 1, 93.

Shuster, S., and Bottoms, E. (1963). Clin. Sci., 25, 487.

— and Scarborough, H. (1961). Quart. J. Med., 30, 33.

Warter, P. J., Drezner, H. L., and Horoschak, S. (1946). J. med. Soc. N.J., 43, 228.

Zweifach, B. W. (1955). Ann. N.Y. Acad. Sci., 61, 670.
La résistance capillaire et l'épaisseur du pli cutané chez des malades atteints d'arthrite rhumatismale et l'effet de la thérapie corticostéroïde

\section{RÉSUMÉ}

On étudia la résistance capillaire et les particularités de la peau dorsale de la main chez 96 malades atteints d'arthrite rhumatismale et 106 témoins. On trouva que cette résistance était basse chez les rhumatisants arthritiques qui ne recevaient pas de traitement stéroïde et normale chez les malades ainsi traités. L'épaisseur du pli cutané, normale chez les premiers, était réduite chez les derniers. On trouva une correlation entre la résistance capillaire et l'épaisseur du pli cutané chez les témoins et chez les malades non-traités, mais non pas chez ceux au régime stéroïde. Une peau transparente et le purpura survenaient plus souvent chez les malades traités. On pense que chez les malades atteints d'arthrite rhumatismale les stéroïdes amènent une modification du tissu conjonctif dermique se manifestant souvent par une peau transparente, le purpura et une réduction de l'épaisseur du pli cutané.

La resistencia capilar y el espesor del pliegue cutáneo en enfermos con artritis reumatoide y el efecto de la terapia corticosteroide

\section{SUMARIO}

Se estudió la resistencia capilar y las particularidades de la piel del dorso de la mano en 96 enfermos con artritis reumatoide y 106 testigos. Se encontró tal resistencia baja en los artríticos reumatoides no tratados por esteroides pero normal en los así tratados. El espesor del pliegue cutáneo, normal en los primeros, fué reducido en los tratados. Se encontró una relación entre la resistencia capilar y el espesor del pliegue cutáneo en los testigos y en los enfermos sin tratar, pero no en enfermos tratados con esteroides. La piel transparente y la púrpura ocurrían más a menudo en los enfermos tratados. Se sugiere que en los enfermos con artritis reumatoide los esteroides ocasionan una alteración del tejido conectivo de la piel, manifestándose a menudo en la piel transparente, la púrpura y la reducción del espesor del pliegue cutáneo. 